\title{
Comparative Analysis of Bankruption Prediction Models in Property and Real Estate Sector Companies Listed on the IDX 2017-2019
}

\author{
Fika Andriani and Pardomuan Sihombing
}

\section{ABSTRACT}

This study takes the topic of comparative analysis of bankruptcy prediction models in the Property and Real Estate Sector companies listed on the IDX in 2017-2019. In this case, the test was conducted to compare the accuracy between the Altman Z-Score, Springate S-Score and Zmijewski X-Score models in predicting the bankruptcy of property and real estate companies. The sample consisted of 20 companies after the sample selection was carried out using purposive sampling technique. To obtain the right level of accuracy, a comparison of the distress or non-distress score categories of each bankruptcy model with the earnings per share (EPS) value of each company was carried out through a dummy variable. Through this test, it is known that the Zmijewski $\mathrm{X}$-Score model is the most accurate model in predicting bankruptcy in the property and real estate sectors listed on the Indonesia Stock Exchange (IDX) by $90 \%$.

Keywords: Bankruptcy Prediction, Altman Z-Score, Springate SScore, Zmijewski X-Score, Earnings Per Share.

JEL Classification: G30, G33, R30.

\section{INTRODUCTION}

Various analytical models have been developed to measure the potential bankruptcy of a company or commonly termed financial distress. This condition occurs when the financial condition has decreased so that a company is no longer able to operate and pay off its obligations. More simply, financial distress shows the condition of the company before bankruptcy or liquidation.

Financial distress analysis is increasingly needed as an early warning system for management to immediately act to save the company and for investors to immediately take anticipatory steps to avoid losses [1].

Among the many bankruptcy analyzes, the model that is often used is the Altman Z-Score [2]. However, some studies show that the Altman Z-Score method does not have the highest accuracy when compared to other measurement methods such as the Springate S-Score [3], [4].

This study takes the object of property and real estate companies due to a decline in home sales in 2019. The main factor that hampers the growth of residential property sales in the second quarter of 2019 is weakening consumer purchasing power. There are also obstacles from licensing and bureaucratic problems. Therefore, further analysis is needed regarding the best financial distress measurement model in property and real estate companies.
Submitted : February 3, 2021

Published : February 19, 2021

ISSN: 2507-1076

DOI: $10.24018 /$ ejbmr.2021.6.1.730

Fika Andriani *

Master of Management, Mercu Buana

University, Jakarta, Indonesia.

(e-mail: fikaandriani2105@ ${ }^{\circledR}$ yahoo.com)

Pardomuan Sihombing

Master of Management, Mercu Buana

University, Jakarta, Indonesia.

(e-mail:

pardomuan.sihombing ${ }^{@}$ mercubuana.ac.id)

*Corresponding Author

\section{LITERATURE REVIEW}

Bankruptcy is a condition when a company is unable to operate due to insufficient funds it has. Sihombing [5] explains that this can happen when a company has very bad financial difficulties so that it is unable to operate properly.

Bankruptcy (bankcruptcy) is a condition in which the company is no longer able to pay off its obligations. This condition usually does not just appear in companies, there are early indications from these companies that can usually be recognized earlier if the financial statements are analyzed more carefully in a certain way [6].

Altman Z-Score is one of three bankruptcy prediction methods. This model applies the Multiple Discriminant Analysis (MDA) method in determining the coefficient of each variable. The advantage of this model is to know the level of financial soundness of the company so that it can be anticipated as early as possible (early warning system) before the company's performance and financial health decline and then finally declared bankrupt. In addition, Altman's bankruptcy discriminant model is included in the multivariate analysis, which means that there is a relationship between the variables of the Z-Score and financial ratio analysis where the financial ratio variables are taken from the financial statements.

While the weaknesses in this model are variables taken from the financial statements so that if the preparation of the financial statements is wrong, the results of the Z-Score value will also no longer be accurate so that they cannot be used as a benchmark to determine whether the company 
will actually go bankrupt or not because management must look at the indicators of company failure.

The Springate S-Score was developed through 4 financial ratios to predict potential financial difficulties in a company. The advantage of this model lies in the use of the ratio of Earnings Before Taxes to Current Liabilities (EBTCL) where this ratio can determine the company's ability to pay its short-term liabilities from Profit Before Tax which has been reduced by Interest. This model has a weakness becausew it does not use a Current Ratio (CACL) which can make bankruptcy calculations more accurate because this ratio is a measure of a company's ability to pay all its short-term liabilities at maturity using the company's available Current Assets.

Zmijewski's model uses ratio analysis that measures the performance, leverage and liquidity of a company for its prediction model. The advantage of this model lies in the use of Current Ratio (CACL) which can make bankruptcy calculations more accurate because this ratio is a measure of the company's ability to pay all of its short-term liabilities at maturity using the company's available Current Assets. While the weakness in this model is due to not using the ratio of Earnings Before Taxes to Current Liabilities (EBTCL) where this ratio can determine the company's ability to pay its short-term obligations from Profit Before Tax which has been reduced by Interest.

The research was conducted by first collecting data on the financial statements of property and real estate companies listed on the Indonesia Stock Exchange (IDX) for the period 2017-20198 from the website www.idx.co.id [13]. Furthermore, predicting the level of financial distress using the Altman Z-Score, Springate S-Score and Zmijewski X-Score models. Then, the accuracy and error rate of each model were tested to compare which results were more precise and accurate.

\section{METHODS}

The type of research used is quantitative research with a descriptive comparative study approach. Descriptive comparatives compare the same variables for different samples.

In this descriptive comparative study (descriptive comparative) aims to compare the accuracy of the Altman Z-Score, Springate S-Score and Zmijewski X-Score models in predicting the bankruptcy of property and real estate companies.

The sample selection was used by using purposive sampling technique in order to obtain 20 companies. This research was conducted using the method of financial statement analysis with the discriminant analysis of Altman Z-score, Springate S-Score and Zmijewski X-Score based on financial report data obtained from the Indonesia Stock Exchange website. The accuracy of the model is used to determine which model is the most appropriate in predicting company bankruptcy.

The accuracy level of the model is calculated by comparing the distress or non-distress score categories of each bankruptcy model with the earnings per share (EPS) value of each company. Earnings per share (EPS) calculated by dividing the net income and the number of outstanding shares or shares outstanding. In this study grouped with size 0 for companies that have positive EPS or not experiencing financial distress and 1 for companies that have negative EPS or experiencing financial distress.

In addition to the accuracy of each model, the error rate of the Altman, Springate and Zmijewski models is also taken into account. There are 2 types of errors, namely error type I and error type II. Type I error is an error that occurs when the model predicts the sample will not experience distress when in fact it experiences distress. Conversely, type II error is an error that occurs when the model predicts the sample will experience distress when in fact it does not experience distress.

\section{RESUlTS AND DisCUSSION \\ A. Model of Company Bankruptcy}

The results of calculations using the Altman Z-Score bankruptcy method show that there are 13 samples of companies in the safe zone and 47 samples of companies in the bankruptcy zone (distress area). The number of company data studied was 60 sample companies. In this study, the gray zone (gray area) obtained in the calculation is assumed to be a bankruptcy zone (distress area) with the consideration that the company applies a conservative pattern in conducting its business. Conservative patterns in business can be interpreted when facing uncertainty falls into the gray zone category, then it is considered to be in the most pessimistic category, namely the bankruptcy zone (distress area).

The results of the calculation using the Springate S-Score bankruptcy method show that there are 26 samples of companies in the safe zone and 34 samples of companies in the bankruptcy zone (distress area). The number of company data studied was 60 sample companies.

The results of calculations using the Zmijewski X-Score bankruptcy method show that there are 56 samples of companies in the safe zone and 4 samples of companies in the bankruptcy zone (distress area). The number of company data studied was 60 sample companies.

\section{B. Accuracy Level and Error Level}

The accuracy of the model is used to determine which model is the most appropriate in predicting company bankruptcy. The accuracy level of the model is calculated by comparing the distress or non-distress score categories of each bankruptcy model with the Earnings Per Share (EPS) value of each company. Earnings Per Share (EPS) can be used as an indicator of a company experiencing financial distress because when a company experiences negative EPS, it means that the net income generated by a company experiences a loss and will be in financial distress.

Earnings Per Share (EPS) is calculated by dividing net income and the number of outstanding shares. In this study grouped with size 0 for companies that have positive EPS or not experiencing financial distress and 1 for companies that have negative EPS or experiencing financial distress. Apart from EPS, there are other ratios that can also be used as an indicator of a company's financial distress, including Return On Assets (ROA), Return On Equity (ROE), Debt 
To Equity (DER), Price To Earning (PER) and Net Profit Margin (NPM).

In addition to the accuracy of each model, the error rate of the Altman, Springate and Zmijewski models is also taken into account. There are 2 types of errors, namely error type I and error type II. Error type I is an error that occurs when the model predicts the sample will not experience distress when in fact 73 experiences distress. Conversely, error type II is an error that occurs when the model predicts the sample will experience distress when in fact it does not experience distress.

TABLE 1: ACCURACY LEVEL AND ERROR LEVEL OF ALTMAN Z-SCORE

\begin{tabular}{cccc}
\hline \multirow{3}{*}{ Year } & \multicolumn{3}{c}{ Altman Model Prediction Accuracy Level } \\
\cline { 2 - 4 } & Correct & Type of Error I & Type of Error II \\
\hline 2017 & 5 & 0 & 15 \\
2018 & 4 & 0 & 16 \\
2019 & 6 & 0 & 14 \\
Amount & 15 & 0 & 45 \\
Number of & 60 & 2 & 58 \\
Samples & $25 \%$ & $0 \%$ & $78 \%$ \\
$\%$ & & & \\
\hline
\end{tabular}

The accuracy rate of the Altman Z-Score model is $25 \%$. Of the 60 total samples, it is known that 15 samples were declared correct. In 2017, out of 20 companies, there were 0 errors in type I error and 15 errors in type II, so there were 5 samples that were declared correct. In 2018 out of 20 companies, there were 0 errors in type I error and 16 errors in type II so that 4 samples were declared correct. In 2019 , out of 20 companies, there were 0 errors in type I error and 14 errors in type II, so there were 6 samples that were declared correct. From the 2017-2019 total, there are 2 samples of companies that actually experience distress (negative EPS), the Altman Z-Score model predicts that 2 samples of these companies experience distress so that the type I error rate is $0 \%$. From a total of 58 samples of companies that did not experience distress (positive EPS), the Altman Z-Score model predicts 45 samples to experience distress and 13 samples not to experience distress so that the type II error rate is $78 \%$.

TABLE 2: ACCURACy LEVEL AND ERROR LEVEL OF SPRINGATE S-SCORE MODEL

\begin{tabular}{cccc}
\hline \multirow{2}{*}{ Year } & \multicolumn{3}{c}{ Springate Model Prediction Accuracy Level } \\
\cline { 2 - 4 } & Correct & Type of Error I & Type of Error II \\
\hline 2017 & 12 & 0 & 8 \\
2018 & 6 & 0 & 14 \\
2019 & 10 & 0 & 10 \\
Amount & 28 & 0 & 32 \\
Number of & 60 & 2 & 58 \\
Samples & $47 \%$ & $0 \%$ & $55 \%$ \\
$\%$ & \multicolumn{3}{c}{} \\
\hline
\end{tabular}

The accuracy rate of the Springate S-Score model is $47 \%$. Of the 60 samples, it is known that 28 samples were declared correct. In 2017, out of 20 companies, there were 0 errors in type I error and 8 errors in type II so that 12 samples were declared correct. In 2018 out of 20 companies, there were 0 errors in type I error and 14 errors in type II so that there were 6 samples that were declared correct. In 2019 out of 20 companies, there were 0 errors in type I error and 10 errors in type II so that there were 10 samples that were declared correct. From the 2017-2019 total, there are 2 samples of companies that actually experience distress (negative EPS), the Springate S-Score model predicts that 2 samples of these companies experience distress so that the type I error rate is $0 \%$. From a total of 58 samples of companies that did not experience distress (positive EPS), the Springate SScore model predicts 32 samples to experience distress and 26 samples not to experience distress so that the type II error rate is $55 \%$.

TABLE 3: ACCURACY LEVEL AND ERROR LEVEL OF ZMIJEWSKI X-SCORE MODEL

\begin{tabular}{|c|c|c|c|}
\hline \multirow{2}{*}{ Year } & \multicolumn{3}{|c|}{$\begin{array}{c}\text { Zmijewski Model's Prediction Accuracy } \\
\text { Level }\end{array}$} \\
\hline & Correct & $\begin{array}{l}\text { Type of } \\
\text { Error I }\end{array}$ & $\begin{array}{l}\text { Type of } \\
\text { Error II }\end{array}$ \\
\hline 2017 & 19 & 0 & 1 \\
\hline 2018 & 19 & 0 & 1 \\
\hline 2019 & 16 & 2 & 2 \\
\hline Amount & 54 & 2 & 4 \\
\hline $\begin{array}{c}\text { Number of } \\
\text { Samples }\end{array}$ & 60 & 2 & 58 \\
\hline$\%$ & $90 \%$ & $100 \%$ & $7 \%$ \\
\hline
\end{tabular}

The accuracy rate of the Zmijewski X-Score model is $90 \%$. Of the 60 total samples, it is known that 54 samples were declared correct. In 2017, out of 20 companies, there were 0 errors in type I error and 1 error in type II so that 19 samples were declared correct. In 2018 out of 20 companies, there were 0 errors in type I error and 1 error in type II so that 19 samples were declared correct. In 2019, out of 20 companies, there were 2 errors in type I error and 2 errors in type II, so there were 16 samples that were declared correct. From the 2017-2019 total, there are 2 samples of companies that actually experience distress (negative EPS), the Zmijewski X-Score model predicts that the 2 samples of these companies will not experience distress so that the type I error rate is $100 \%$. From a total of 58 samples of companies that did not experience distress (positive EPS), the Zmijewski XScore model predicts 4 samples to experience distress and 54 samples not to experience distress so that the type II error rate is $7 \%$.

\section{Calculation of the Altman Z-Score Bankruptcy Model}

The results of calculations using the Altman ZScore bankruptcy method show that there are 13 samples of companies in the safe zone and 47 samples of companies in the bankruptcy zone (distress area). The number of company data studied was 60 sample companies.

\section{Calculation of the Springate S-Score Bankruptcy Model}

The results of calculations using the Springate S-Score bankruptcy method show that there are 26 samples of companies in the safe zone and 34 samples of companies in the bankruptcy zone (distress area). The number of company data studied was 60 sample companies.

\section{E. Calculation of the Zmijewski X-Score Bankruptcy Model}

The results of calculations using the Zmijewski X-Score bankruptcy method show that there are 56 samples of companies in the safe zone and 4 samples of companies in the bankruptcy zone (distress area). The number of company data studied was 60 sample companies. 


\section{F. Comparison of Altman, Springate and Zmijewski Models}

The following is a recapitulation of data for calculating the level of accuracy and error level of the Altman, Springate and Zmijewski models:

TABLE 4: RECAPITULATION OF LEVEL OF ACCURACY AND ERROR LEVEL OF PREDICTION MODEL

\begin{tabular}{cccc}
\hline \multicolumn{4}{c}{ OF PREDICTION MODEL } \\
\hline \multirow{2}{*}{ Prediction Model } & $\begin{array}{c}\text { Level of } \\
\text { accuracy }\end{array}$ & $\begin{array}{c}\text { Type I Error } \\
\text { Level }\end{array}$ & $\begin{array}{c}\text { Type II Error } \\
\text { Level }\end{array}$ \\
\hline Altman & $25 \%$ & $0 \%$ & $78 \%$ \\
Springate & $47 \%$ & $0 \%$ & $55 \%$ \\
Zmijewski & $90 \%$ & $100 \%$ & $7 \%$ \\
\hline
\end{tabular}

The highest level of accuracy is the Zmijewski model with an accuracy rate of $90 \%$. The second position is the Springate model with an accuracy rate of $47 \%$ and the last position is the Altman model with an accuracy rate of $25 \%$. However, Altman 's accuracy is influenced by the company category which is assumed to be in the healthy category (safe area) even though it should be in the gray zone.

This study has results that are in line with previous studies [7], [8]. In addition, there are previous studies with conflicting results [4], [9].

\section{CONCLUSION}

From the number of company data studied as many as 60 company samples, the results of calculations using the Altman Z-Score bankruptcy method show that there are 13 samples of companies in the safe zone and 47 samples of companies in the bankruptcy zone (distress area). The calculation using the Springate S-Score bankruptcy method shows that there are 26 samples of companies that are in the safe zone and 34 samples of companies are in the bankruptcy zone (distress area) and the results of calculations using the Zmijewski X-Score bankruptcy method show that there are 56 samples of companies in the safe zone and 4 samples of companies in the bankruptcy zone (distress area). My research shows that the Zmijewski $\mathrm{X}$-Score model is the most accurate model in predicting bankruptcy in the property and real estate sectors listed on the Indonesia Stock Exchange (IDX) for the 2017-2019 period with an accuracy rate of $90 \%$ compared to the Springate S-Score model with an accuracy rate of $47 \%$ and the Altman Z-Score model with the lowest accuracy rate of $25 \%$.

\section{A. Limitation}

This study has a limited number of samples and periods, only a 3-year period from 2017-2019 in 20 property and real estate sector companies listed on the Indonesia Stock Exchange (IDX). In addition, this study only uses three bankruptcy prediction models, namely the Altman Z-Score, the Springate S-Score and the Zmijewski X-Score.

\section{B. Suggestion}

Based on the results of the research and the conclusions obtained, it is hoped that further studies can be developed even better by following the existing suggestions, namely: 1) Overall, the results of the study show that the bankruptcy prediction using the Altman, Springate and Zmijewski bankruptcy models in property and real estate sector companies listed on the Indonesia Stock Exchange has a relatively high potential for bankruptcy so that it is expected to be taken into consideration by investors in investing. in property and real estate sector companies listed on the Indonesia Stock Exchange (IDX), 2) PT. Indonesia Pondasi Raya Tbk (IDPR) and PT. Ristia Bintang Mahkotasejati Tbk (RBMS) had a negative net income in 2019. This can be a concern and it is recommended for company management to be able to better manage company finances in the future, 3) This study uses a 3-year period with 20 property and real estate sector companies listed on the Indonesia Stock Exchange. Further research is suggested to increase the number of samples and a longer period to be used in research, 4) Further research is suggested to try to apply research to 8 other sectors in the Indonesia Stock Exchange (IDX) such as agriculture (agriculture), mining (mining), basic industry (basic and chemical industries), miscellaneous (various industries), consumer goods (consumer goods industry), infrastructure (infrastructure, utilities and transportation), finance (finance) and trade (trade, services and investment), 5) Further research is suggested to add other bankruptcy prediction models that will be used such as the Fulmer H-Score, Ohlson O-Score, Neuro Fuzzy Algorithm, Beaver, Zavgren (Logit Model), Beneish M-Score, CA-Score, Wilcox and so on.

\section{REFERENCES}

[1] Piliang, Endri. 2009. Prediksi Kebangkrutan Bank Untuk Menghadapi Dan Mengelola Perubahan Lingkungan Bisnis: Analisis Model Altman's Z-Score. Perbanas Quarterly Review, 2(1).

[2] Rafles, dkk. 2015. Analisis Prediksi Kebangkrutan Perusahaan Dengan Menggunakan Metode Altman (Z-Score) (Studi pada Subsektor Rokok yang Listing dan Perusahaan Delisting di Bursa Efek Indonesia Tahun 2009 - 2013). Jurnal Administrasi Bisnis (JAB), 2(1).

[3] Supriati, Diana, Icuk R. Bawono, dan Kusriyadi C. Anam. 2019. Analisis Perbandingan Model Springate, Zmijewski, dan Altman dalam Memprediksi Financial Distress Pada Perusahaan Manufaktur yang Terdaftar di Bursa Efek Indonesia. Journal of Business Administration, 3(2), 258-270.

[4] Priambodo, Dimas, dan Adeng Pustikaningsih. 2018. Analisis Perbandingan Model Altman, Springate, Grover, Dan Zmijewski Dalam Memprediksi Financial Distress (Studi Empiris Pada Perusahaan Sektor Pertambangan Yang Terdaftar Di Bursa Efek Indonesia Periode 2012-2015). Jurnal Pendidikan Akuntansi, 6(4).

[5] Sihombing, Pardomuan. 2018. Corporate Financial Management. Cetakan 1. Bogor: Penerbit IPB Press.

[6] Toto, Prihadi. 2011. Analisis Laporan Keuangan Teori dan Aplikasi. Jakarta: PPM.

[7] Yami, Nafir Rizky Herlambang, dan Ririh Dian Pratiwi. 2017. Prediksi Kebangkrutan Dengan Menggunakan Metode Altman ZScore, Springate Dan Zmijewski Pada Perusahaan Property Dan Real Estate Yang Terdaftar Di BEI Tahun 2011-2013. Jurnal Akuntansi Universitas Dian Nuswantoro, 2(4).

[8] Munawarah, Anton Wijaya, Cindy Fransisca, Felicia, dan Kavita. 2019. Ketepatan Altman, Zmijewski, Grover, dan Fulmer menentukan Financial Distress pada Perusahaan Trade and Service. Riset \& Jurnal Akuntansi, 3(2).

[9] Edi, dan May Tania. 2018. Ketepatan Model Altman, Springate, Zmijewski, dan Grover dalam Memprediksi Financial Distress. Jurnal Reviu Akuntansi dan Keuangan, 8(1), 79-92.

[10] Altman, E. I. 1968. Financial Ratios, Discriminant Analysis and The Prediction of Corporate Bankruptcy. The Journal of Finance, 23(4).

[11] Springate, G.L.V. 1978. Predicting the Possibility of Failure in a Canadian Firm. Tesis. Tidak Diterbitkan. Simon Fraser University: Canada.

[12] Zmijewski, M.E. 1984. Methodological Issues Relate to the Estimation of Financial Distress Prediction Models. Journal of Accounting Research, 22, 59-82.

[13] https://www.idx.co.id/. 